\title{
Synthesis, Characterization and Antioxidant Activity of Novel 3-(2,5-dioxo-imidazolidin-1-yl)-1,1- diethylurea Derivatives
}

\author{
H. N. DEEPAKUMARI ${ }^{1 *}$, M. S. RAGHU ${ }^{2}$ and C. B. PRADEEP KUMAR ${ }^{3}$ \\ ${ }^{1}$ Department of Chemistry, Bharathi College, Bharathinagara, Mandya-571422, India \\ ${ }^{2}$ Department of Chemistry, New Horizon College of Engineering, Bangalore-560103, India \\ ${ }^{3}$ Department of Chemistry, Malnad College of Engineering, Hassan-573202, India \\ deepakumari_22@yahoo.com
}

Received 10 May 2019 / Accepted 2 July 2019

\begin{abstract}
A novel class of hydantoin derivatives was synthesized and their antioxidant activity was evaluated. The newly synthesized compounds were characterized using ${ }^{1} \mathrm{H}$ NMR, IR, Mass spectra and elemental analysis. The antioxidant activity of synthesized compounds (3a-d) were examined by 2,2-diphenyl-1-picrylhydrazyl (DPPH), nitric oxide hydroxyl radical scavenging assay. It is revealed from the antioxidant screening results that the compounds $\mathbf{3 a}$ and $\mathbf{3 d}$ manifested profound antioxidant potential.
\end{abstract}

Keywords: Hydantoin, DPPH, Nitric oxide, Antioxidant, Hydroxyl radical

\section{Introduction}

Hydantoins, a class of cyclic imides, have attracted continuing interest over the years because of the use of its ring system as important core structure in many drug substances. Depending on the nature of substitution on the hydantoin ring, a wide range of other pharmacological properties, e.g., antihypertensive ${ }^{1}$, herbicidal ${ }^{2}$, antitumor $^{3}$, anti-HIV ${ }^{4}$, antibacterial $^{5}$ and antiviral ${ }^{6}$ activities have also been identified.

The search for new molecules with anti-oxidant properties is a very active domain of research, since they can protect the human body from free radicals and retard the progress of many chronic diseases ${ }^{7}$. High levels of free radicals can cause damage to biomolecules such as lipids, proteins, enzymes and DNA in cells and tissues. This may result in many diseases such as: cancer, diabetes, cardiovascular and autoimmune diseases, and neurodegenerative disorders, aging, and other diseases through the violent reactivity of the free radicals ${ }^{8}$.

Based on these findings, and in view of the significant biological potential alluded by hydantoins, it was though worthwhile to design and synthesize a new series of biologically active hydantoin derivatives. 


\section{Experimental}

The starting materials and reagents were obtained from commercial suppliers and were used without further purification. Melting points were determined in one end open capillary tubes on a Buchi 530 melting point apparatus and are uncorrected. The ${ }^{1} \mathrm{H}$ and ${ }^{13} \mathrm{C}$ NMR spectra were recorded on Bruker Advance $400 \mathrm{MHz}$ NMR instrument using TMS as internal standard and DMSO- $\mathrm{d}_{6}$ as solvent. The FT-IR spectra were recorded using nujal on FT-IR Jasco 4100 infrared spectrophotometer. Column chromatography was performed using Merck 7734 silica gel (60-120 mesh) and Merck made pre-coated TLC plates were used. Elemental analysis (C, H, and N) was undertaken with Perkin-Elmer model 240C analyzer and the data showed good agreement between the experimentally determined values and the theoretically calculated values within $\pm 0.4 \%$.

\section{Synthesis}

\section{Synthesis of ethyl diethylcarbamate (1)}

Diethylamine $(6 \mathrm{mmol})$ was refluxed with propionyl chloride $(6.2 \mathrm{mmol})$ in THF $(25$ $\mathrm{mL})$ and in the presence of triethylamine $(6.2 \mathrm{mmol})$. Then the reaction mixture was stirred at room temperature for about $8 \mathrm{~h}$. After completion of the reaction (TLC), the reaction mixture was quenched in ice cold water and extracted with dichloromethane. The ether layer was washed with $5 \% \mathrm{NaHCO}_{3}$ and dried over $\mathrm{Na}_{2} \mathrm{SO}_{4}$ and concentrated in vacuo to give the light brown product. Yield: $92 \% .{ }^{1} \mathrm{H}$ NMR $\left(300 \mathrm{MHz}, \mathrm{DMSO}-\mathrm{d}_{6}\right) \delta$ : $4.13\left(\mathrm{q}, 2 \mathrm{H},-\mathrm{CH}_{2}\right), 3.72\left(\mathrm{q}, 4 \mathrm{H},-\mathrm{CH}_{2}\right), 1.34\left(\mathrm{t}, 6 \mathrm{H},-\mathrm{CH}_{3}\right), 1.26\left(\mathrm{t}, 3 \mathrm{H},-\mathrm{CH}_{3}\right) . \mathrm{MS}, \mathrm{m} / \mathrm{z}$ : $145\left(\mathrm{M}^{+}\right)$. Anal. calc. for $\left(\mathrm{C}_{7} \mathrm{H}_{15} \mathrm{NO}_{2}\right): \mathrm{C} 57.90 ; \mathrm{H} 10.41 ; \mathrm{N} \mathrm{9.65;} \mathrm{found:} \mathrm{C} 57.95 ; \mathrm{H}$ $10.49 ; \mathrm{N} 9.72$.

\section{Synthesis of 3-(2,5-dioxoimidazolidin-1-yl)-1,1-diethylurea (2)}

To a solution of amine ( 1 equiv.) in THF at $0{ }^{\circ} \mathrm{C}$ was slowly added dimethylaluminium chloride (1 equiv.). After the addition was completed, the ice-bath was removed. The resulting solution was stirred for $30 \mathrm{~min}$ and then compound 1 (1 equiv.) was added. The mixture was further stirred for $6 \mathrm{~h}$ at r.t. Aqueous potassium tartrate tetrahydrate was added slowly, the organic layer was separated, and the aqueous phase washed with $25 \mathrm{~mL}$ of $\mathrm{CHCl}_{3}(3 \mathrm{x})$. The organic extracts were combined and washed with brine, dried (anhydrous $\mathrm{Na}_{2} \mathrm{SO}_{4}$ ) and concentrated in vacuo. Recrystallization from absolute EtOH gave product 2. Yield: $90 \% .{ }^{1} \mathrm{H}$ NMR (300 MHz, DMSO-d $\left.{ }_{6}\right) \delta: 8.43(\mathrm{~s}$, $1 \mathrm{H}, \mathrm{NH}), 8.12(\mathrm{~s}, 1 \mathrm{H}, \mathrm{NH}), 3.89\left(\mathrm{q}, 4 \mathrm{H},-\mathrm{CH}_{2}\right), 3.62\left(\mathrm{~s}, 2 \mathrm{H},-\mathrm{CH}_{2}\right), 1.34\left(\mathrm{t}, 6 \mathrm{H},-\mathrm{CH}_{3}\right)$. MS, m/z: $145\left(\mathrm{M}^{+}\right)$. Anal. calc. for $\left(\mathrm{C}_{8} \mathrm{H}_{14} \mathrm{~N}_{4} \mathrm{O}_{3}\right): \mathrm{C} 44.85 ; \mathrm{H}$ 6.59; N 26.15; found: $\mathrm{C}$ $44.81 ; \mathrm{H} 6.55$; N 26.23 .

\section{Synthesis of $(\mathbf{3 a}-\mathbf{d})$}

A solution of compound $2(0.1 \mathrm{mmol})$ in dimethylformamide $(1 \mathrm{~mL})$ was taken and cooled to $0-5{ }^{\circ} \mathrm{C}$ in an ice bath. Triethylamine $(0.12 \mathrm{mmol})$ was added to cold reaction mixture and stirred for $30 \mathrm{~min}$. To the mixture different substituted phenyl thiocyanates $(0.1 \mathrm{mmol})$ was added and allowed to stir at room temperature for $4 \mathrm{~h}$. The progress of the reaction was monitored by TLC. Upon completion, the reaction mixture was diluted with water and extracted with ethyl acetate. The organic layer was washed with water and dried over anhydrous sodium sulfate. The filtrate was concentrated in vacuo to get the crude product which was purified by column chromatography over silica gel (60-120 mesh) using hexane: ethyl acetate (9:1) as eluent to afford the compound 3a-d in good yields. 


\section{3-(3,3-Diethylureido)-N-(4-hydroxyphenyl)-2,4-dioxoimidazolidine-1- carbothioamide (3a)}

Yield: $89 \% .{ }^{1} \mathrm{H}$ NMR $\left(300 \mathrm{MHz}, \mathrm{DMSO}_{-} \mathrm{d}_{6}\right) \delta: 10.1$ (s, 1H, Ar-OH), $8.83(\mathrm{~s}, 1 \mathrm{H}, \mathrm{CONH})$, $8.41(\mathrm{~s}, 1 \mathrm{H}, \mathrm{CSNH}), 7.42-7.12(\mathrm{~m}, 4 \mathrm{H}, \mathrm{Ar}-\mathrm{H}), 4.01\left(\mathrm{~s}, 2 \mathrm{H},-\mathrm{CH}_{2}\right), 3.89$ (q, 4H, $\left.-\mathrm{CH}_{2}\right), 1.34$ $\left(\mathrm{t}, 6 \mathrm{H},-\mathrm{CH}_{3}\right)$. IR (nujol, $\left.\mathrm{cm}^{-1}\right): 3439(\mathrm{Ar}-\mathrm{OH}), 3235,3215(\mathrm{~N}-\mathrm{H}), 1708,1675,1639(\mathrm{C}=\mathrm{O})$. MS, m/z: $366\left(\mathrm{M}^{+}\right)$. Anal. Calc. For $\left(\mathrm{C}_{15} \mathrm{H}_{19} \mathrm{~N}_{5} \mathrm{O}_{4} \mathrm{~S}\right)$ : C 49.30; H 5.24; $\mathrm{N} \mathrm{19.17;} \mathrm{found:} \mathrm{C}$ 49.37; H 5.21; N 19.23 .

\section{3-(3,3-Diethylureido)-2,4-dioxo- $N$-(p-tolyl)imidazolidine-1-carbothioamide (3b)}

Yield: $87 \% .{ }^{1} \mathrm{H}$ NMR $\left(300 \mathrm{MHz}, \mathrm{DMSO}_{6}\right) \delta: 8.81$ (s, 1H, CONH), 8.45 (s, 1H, CSNH), 7.45-7.12 (m, 4H, Ar-H), $4.02\left(\mathrm{~s}, 2 \mathrm{H},-\mathrm{CH}_{2}\right), 3.81$ (q, 4H, $\left.-\mathrm{CH}_{2}\right), 2.32\left(\mathrm{~s}, 3 \mathrm{H}, \mathrm{Ar}-\mathrm{CH}_{3}\right), 1.32$ (t, $\left.6 \mathrm{H},-\mathrm{CH}_{3}\right)$. IR (nujol, $\left.\mathrm{cm}^{-1}\right)$ : 3235, $3210(\mathrm{~N}-\mathrm{H}), 1708,1670,1635(\mathrm{C}=\mathrm{O}) . \mathrm{MS}, \mathrm{m} / \mathrm{z}: 364\left(\mathrm{M}^{+}\right)$. Anal. Calc. For $\left(\mathrm{C}_{16} \mathrm{H}_{21} \mathrm{~N}_{5} \mathrm{O}_{3} \mathrm{~S}\right)$ : C 52.88; H 5.82; N 19.27; found: C 52.81; H 5.89; N 19.35.

\section{3-(3,3-Diethylureido)-N-(4-methoxyphenyl)-2,4-dioxoimidazolidine-1- carbothioamide $(\mathbf{3 c})$}

Yield: $83 \% .{ }^{1} \mathrm{H}$ NMR (300 MHz, DMSO-d $\left.\mathrm{d}_{6} \odot-\right) \delta: 8.83$ (s, 1H, CONH), 8.43 (s, 1H, CSNH), 7.41-7.13 (m, 4H, Ar-H, 5), 4.14 (s, 2H, - $\mathrm{CH}_{2}$ ), 3.97 (q, 4H, - $\mathrm{CH}_{2}$ ), 3.79 (s, 3H, $\left.-\mathrm{OCH}_{3}\right), 1.32$ (t, $6 \mathrm{H},-\mathrm{CH}_{3}$ ). IR (nujol, $\left.\mathrm{cm}^{-1}\right): 3235,3215(\mathrm{~N}-\mathrm{H}), 1706,1675,1632(\mathrm{C}=\mathrm{O}) . \mathrm{MS}, \mathrm{m} / \mathrm{z}: 380\left(\mathrm{M}^{+}\right)$. Anal. Calc. For $\left(\mathrm{C}_{16} \mathrm{H}_{21} \mathrm{~N}_{5} \mathrm{O}_{4} \mathrm{~S}\right)$ : C 50.65; H 5.58; N 18.46; found: C 50.61; H 5.63; N 18.54.

$N$-(4-aminophenyl)-3-(3,3-diethylureido)-2,4-dioxoimidazolidine-1-carbothioamide (3d)

Yield: $85 \% .{ }^{1} \mathrm{H}$ NMR (300 MHz, DMSO-d $\left.\mathrm{d}_{6}\right) \delta: 8.81$ (s, 1H, CONH), 8.46 (s, 1H, CSNH), 7.44-7.12 (m, 4H, Ar-H, 5), 5.71 (s, 2H, $\left.-\mathrm{NH}_{2}\right), 4.12\left(\mathrm{~s}, 2 \mathrm{H},-\mathrm{CH}_{2}\right), 3.97$ (q, 4H, $\left.-\mathrm{CH}_{2}\right), 1.32$ $\left(\mathrm{t}, 6 \mathrm{H},-\mathrm{CH}_{3}\right)$. IR (nujol, $\left.\mathrm{cm}^{-1}\right): 3379\left(\mathrm{NH}_{2}\right), 3235,3213(\mathrm{~N}-\mathrm{H}), 1710,1671,1640(\mathrm{C}=\mathrm{O})$. MS, m/z: $365\left(\mathrm{M}^{+}\right)$. Anal. Calc. For $\left(\mathrm{C}_{15} \mathrm{H}_{20} \mathrm{~N}_{6} \mathrm{O}_{3} \mathrm{~S}\right)$ : C 49.44; H 5.53; N 23.06; found: $\mathrm{C}$ 49.48; H 5.59; N 23.15.

\section{Antioxidant activity}

All synthesized compounds were tested for antioxidant activity by 1,1-diphenyl-2-picryl hydrazyl (DPPH), nitric oxide (NO) and hydroxyl radical scavenging methods. Standard procedures were followed for the determination of free radical scavenging activity

\section{Results and discussion}

\section{Synthesis}

The syntheses of the compounds 3a-d were accomplished according to the reaction sequence illustrated in Scheme 1. The synthesis begins from condensation of diethyl amine with propionyl chloride in tetrahydrofuran (THF) afford the compound $\mathbf{1}$. The key intermediate compound 2 was obtained by the reacting compound 1 with 3-aminoimidazolidine-2,4dioneunder reflux for $12 \mathrm{~h}$. Finally the compound 2 was coupled with different substituted isothiocyanatobenzene to afford the desired compounds 3a-d with good yields (84-91\%). The structures of the synthesized compounds were deduced on the basis of ${ }^{1} \mathrm{H}$ NMR, IR and mass spectra. The composition of all the compounds was obtained by elemental analysis. In addition, the chemical shift and multiplicity patterns correlated well with the proposed structures. The elemental analysis data showed good agreement between the experimentally determined values and the theoretically calculated values. 


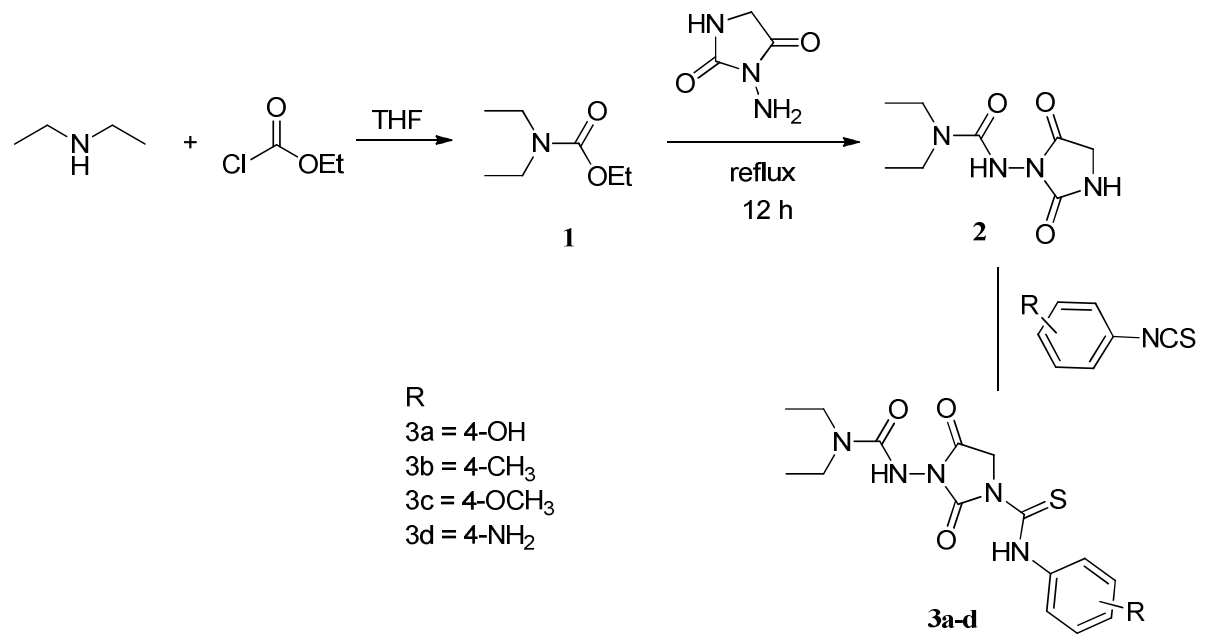

Scheme 1. Reaction scheme of hydantoin derivatives (3a-d)

\section{Antioxidant activity}

Radical scavenging potency of the synthesized compounds 3a-d was assessed in vitro by the $\mathrm{DPPH}^{9}$, hydroxyl ${ }^{10}$ and nitric oxide radical scavenging ${ }^{11}$ methods in comparison with the standards, namely ascorbic acid and BHA. The results are presented in Table 1.

Table 1. Antioxidant activity of the synthesized compounds

\begin{tabular}{cccc}
\hline \multirow{2}{*}{ Compounds } & \multicolumn{3}{c}{$\mathrm{IC}_{50}, \mu \mathrm{g} / \mathrm{mL}$} \\
\cline { 2 - 4 } & $\mathrm{DPPH}$ & Nitric oxide & Hydroxyl \\
\hline 3a & $12.7 \pm 0.06$ & $13.4 \pm 0.64$ & $10.6 \pm 0.03$ \\
3b & $46.5 \pm 0.69$ & $59.1 \pm 0.78$ & $48.9 \pm 0.5110 .6 \pm 0.03$ \\
3c & $38.6 \pm 0.55$ & $55.9 \pm 0.67$ & $48.1 \pm 0.71$ \\
3d & $13.1 \pm 0.14$ & $14.1 \pm 0.53$ & $11.7 \pm 0.18$ \\
$\mathrm{AA}^{\mathrm{a}}$ & $12.6 \pm 0.43$ & $\mathrm{n} . \mathrm{t}^{\mathrm{c}}$ & $\mathrm{n} . \mathrm{t}^{\mathrm{c}}$ \\
BHA $^{\mathrm{b}}$ & $\mathrm{n}^{\mathrm{c}} \mathrm{t}^{\mathrm{c}}$ & $14.3 \pm 0.18$ & $15.3 \pm 0.47$ \\
\hline \multicolumn{4}{c}{${ }^{\text {a }}$ ascorbic acid, ${ }^{b}$ butylatedhydroxyanisole, ${ }^{c}$ not tested }
\end{tabular}

The stable free radical DPPH is a useful reagent to investigate the scavenger properties of phenols, catechols, and anilines. This assay evaluates the ability of the substance under examination to donate $\mathrm{H}$ atoms and quench the visible absorption at $515 \mathrm{~nm}$ of the nitrogen radical of $\mathrm{DPPH}^{12}$. There are many reports describing the antiradical effect of phenolic compounds by DPPH assay. On other hand, it is well-established that organic molecules incorporating an electron donating group (amine, hydroxyl and methoxy) moiety can act as free radical trapping agents and are capable of opposing oxidative challenges.

All the compounds (3a-d) showed comparable or slightly less activity to the standards (ascorbic acid and BHA). The antioxidant activity was expressed as the 50\% inhibitory concentration $\left(\mathrm{IC}_{50}\right)$ based on the amount of compound required for a $50 \%$ decrease in the initial DPPH radical concentration. It was observed that all the compounds notably reduced the concentration of DPPH free radical.

The difference in radical scavenging activity of the synthesized hydantoin compounds (3a-d) were due to the difference in the stability of the oxygen centred radical formed in 
these compounds. The better activity of compound $\mathbf{3 a}\left(\mathrm{IC}_{50} 12.7 \mu \mathrm{g} / \mathrm{mL}\right)$ having hydroxyl group at $\mathrm{p}$ - position in the aromatic ring is due to high electron-releasing properties (positive mesomeric effect is higher than negative inductive effect) and this activates the aromatic ring. The compound $\mathbf{3 d}\left(\mathrm{IC}_{50} 13.1 \mu \mathrm{g} / \mathrm{mL}\right)$ bearing an electron donating amine group at para position showed better DPPH radical scavenging activity compared to $\mathbf{3 b}$ and $\mathbf{3 c}$.

Hydroxyl radical scavenging capacity of synthesized compounds (3a-d) is directly related to its antioxidant activity and hydroxyl radicals are the major active oxygen species causing lipid oxidation and enormous biological damage ${ }^{13} . \mathrm{IC}_{50}$ values (Table 1) of all tested compounds through hydroxyl radical scavenging activity test were ranging from 10.6 to $48.9 \mu \mathrm{g} / \mathrm{mL}$. In this study, compound 3a exhibited the strongest antioxidant activity (10.6 $\mu \mathrm{g} / \mathrm{mL})$, followed by the compound $\mathbf{3 d}(11.7 \mu \mathrm{g} / \mathrm{mL})$ and the compound $\mathbf{3 b}(48.9 \mu \mathrm{g} / \mathrm{mL})$ which showed the weakest activity.

In addition to reactive oxygen species, nitric oxide has a key role in various types of inflammatory processes and is a potent pleiotropic inhibitor of physiological processes. It is a diffusible free radical that plays many roles as an effectors molecule in diverse biological systems including neuronal messenger, vasodilatation and antimicrobial and antitumor activities ${ }^{14}$. The nitric oxide radical scavenging activity indicates that the $\mathrm{OH}$ and $\mathrm{NH}_{2}$ substitution in the phenyl group is the main factor responsible for the scavenging effect of this reactive nitrogen species. Compounds $\mathbf{3 a}$ and $\mathbf{3 d}$ were the most effective ones with $\mathrm{IC}_{50}$ value 13.4 and $14.1 \mu \mathrm{g} / \mathrm{mL}$, respectively.

\section{Conclusion}

The synthesis and electrochemical investigation of novel hydantoin derivatives may draw the following conclusions: (i) A series of hydantoin derivatives was prepared and tested for their antioxidant activity. These compounds offer the advantage of a facile synthesis. (ii) Further, the compounds 3a and 3d displayed pronounced antioxidant activity as interpreted by the results of DPPH, superoxide and hydroxyl radical scavenging assays. On the basis of above observations, we will further modify to improve the antidepressant activity of piperamides.

\section{Acknowledgement}

One of the authors H. N. Deepakumari grateful to the UGC, New Delhi for providing the minor research project.

\section{References}

1. Edmunds J J, Klutchko S, Hamby J M, Bunker A M, Connolly C J C, Winters R T, Quin J, I. Stircar I, Hodges J C, Panek R L, Keiser J A and Doherty A M, J Med Chem., 1995, 38(19), 3759-3771; DOI:10.1021/jm00019a005

2. Hanessian S, Sanceau J Y and Chemla P, Tetrahedron, 1995, 51(24), 6669-6678; DOI:10.1016/0040-4020(95)00324-2

3. Ahmed K I, Carbohydr Res., 1998, 306, 567-573.

4. Comber R N, Reynolds R C, Friedrich J D, Manguikian R A, Buckheit R W, Truss J J W, Shannon W M and Secrist J A, J Med Chem., 1992, 35(19), 3567-3572; DOI:10.1021/jm00097a014

5. Oh C H, Kim H J, Hong S Y, Lee Y H, Cho J K and Cho J H, Arch Pharm., 1995, 328(4), 385-387; DOI:10.1002/ardp.19953280418 
6. Kim D, Wang L, Caldwell C G, Chen P, Finke P E, Oates B, MacCoss M, Mills S G, Malkowitz L, Gould S L, DeMartino J A, Springer M S, Hazuda D, Miller M, Kessler J, Danzeisen R, Carella G, Holmes K, Lineberger J, Schleif W A and Emini E A, Bioorg Med Chem Lett., 2001, 11(24), 3099-3102; DOI:10.1016/S0960894X(01)00654-0

7. Suthakaran R, Kavimani S, Venkaiaiah P and Suganthi K, Rasayan J Chem., 2008, 1(1), 22-29.

8. Prashanth M K, Revanasiddappa H D, Rai K M L and Veeresh B, Bioorg Med Chem Lett.,, 2012, 22(23), 7065-7070; DOI:10.1016/j.bmcl.2012.09.089

9. Blois M S, Nature, 1958, 181, 1199-1200; DOI:10.1038/1811199a0

10. Jayabharathi J, Thanikachalam V, Rajendraprasath N, Saravanan K and Perumal M V, Med Chem Res., 2012, 21(8), 1850-1860; DOI:10.1007/s00044-011-9702-5

11. Padmaja A, Rajasekhar C, Muralikrishna A and Padmavathi V, Eur J Med Chem., 2011, 46(10), 5034-5038; DOI:10.1016/j.ejmech.2011.08.010

12. Goupy P, Dufour C, Loonis M and Dangles Q, J Agric Food Chem., 2003, 51(3), 615-622; DOI:10.1021/jf0259381

13. Chance B, Sies H and Boveris A, Physiol Rev., 1979, 59(3), 527-605; DOI:10.1152/physrev.1979.59.3.527

14. Vriesman M F, Haenen M M, Westerveld G J, Paquay J B J, Voss H P and Bast H P, Pharm World Sci., 1997, 19(6), 283-286; DOI:10.1023/A:1008601327920 